\title{
Hypoglycemic and anti-diabetic activity of ethanolic extract of Catharanthus pusillus (murray) g.don
}

\author{
A. Navitha ${ }^{1}$, D. A. Helen Sheeba ${ }^{2}$, C. Ramesh ${ }^{3}$, M. Sartaj Banu ${ }^{4}$ \\ 1, 2, 4 (Department of Pharmacology, Malla Reddy Institute of Pharmaceutical Sciences, \\ Hyderabad - 500070, India) \\ 3(Department of Pharmacology, GSN Pharmaceuticals Pvt. Ltd., Kukatpally, \\ Hyderabad- 500072, India)
}

\begin{abstract}
Many plant drugs are studied for effecting in the treatment of Diabetes mellitus. In the present study ethanolic extract of herb of Catharanthus pusillus was evaluated for hypoglycemic effect in Streptozotocin induced diabetic rats using both 18 hour fasted rat model and oral glucose tolerance test. A comparison was made between the actions of ethanolic extract Catharanthus Pusillus and known anti diabetic drug Glibenclamide (5 mg/kg, p.o). The ethanolic extract of Catharanthus Pusillus was administered at different doses to normal and diabetic rats. The ethanolic extract at $500 \mathrm{mg} / \mathrm{kg}$ body weight dose level exhibited significant hypoglycemic activity $(P<0.01$ and $P<0.001)$. Phytochemical screening of aqueous, methanolic, ethanolic and chloroform extract revealed the presence of alkaloids, saponins and carbohydrates. It is concluded that ethanolic extract of herb of Catharanthus Pusillus posses anti diabetic activity.
\end{abstract}

Keywords-Hypoglycemic activity, Oral glucose tolerance test, Catharanthus Pusillus Streptozotocin induced Diabetes.

\section{INTRODUCTION}

Non insulin dependent diabetes mellitus, type 2 (NIDDM) can be manifested by chronic hyperglycemia due to defects in insulin secretion, insulin action and or both ${ }^{[16]}$. It is common disorder among the Indian population. Therapeutic options for diabetes are diet, exercise, oral hypoglycemic drugs and insulin therapy. In India number of alternative medicines like Ayurvedic as well as Sidha preparations have attracted great interest in type 2 diabetes mellitus management ${ }^{[2]}$, Catharanthus Pusillus (C. Pusillus) is one such Ayurvedic herbal formulation. Currently 170 million people world wise affected by diabetes mellitus. Statistical projections about India suggested that 57 million Indians will be affected by diabetes mellitus by the year 2025 making the country with highest number of diabetics in the world ${ }^{[1]}$.

Catharanthus Pusillus belonging to family Apocynaceae is known with various names in India and all over the world. In India seven flowers/ leaves of Catharanthus species are used at a time whereas in the Cook Islands 18 leaves boiled in a kettle of water and in the west indies roots of plants infused in whiskey are used traditionally ${ }^{[3]}$. In the present study we have evaluated Hypoglycemic activity in ethanolic extract of herb of Catharanthus Pusillus and the comparison was made between the actions of ethanolic extract Catharanthus Pusillus and anti-diabetic drug Glibenclamide.

\section{MATERIALS AND METHODS}

\subsection{Plant Material}

Herb of Catharanthus Pusillus ${ }^{[12]}$ was collected after authentication by Dr. K. Madhava chetty, assistant professor, department of botany, Sri Venkateswara University, Tirupati, Andhra Pradesh, India. The plant was collected from the chitturu forest; collected plant was washed thoroughly with water and dreid in the shade. Dreid plant was made into powder in a grinder and were extracted with 10 volumes of ethanol and macerated at room temperature in ethanol for 24 hours. The extract was suctioned and filtered using whatmann filter paper. This was repeated for two more days and similar extracts were pooled together and concentrated at 40 degrees under reduced pressure using buchi R-153 rotavapour. The ethanolic extract was used for further study.

2.2 Experimental Animals

The experiments were performed in adult albino wister rats weighing from $200-240 \mathrm{gm}$. The animals maintained at 23+1 degrees, 55+5\% humidity, 12 hours light and 12 hours dark cycle. Animals had free access to diet and water followed by standard laboratory animal diet conditions ${ }^{[6]}$. 


\subsection{Chemicals}

Streptozotocin purchased from SISCO research laboratories Pvt. Ltd, Mumbai. All chemicals used for this study were analytical grade.

\subsection{Study on Glucose Loaded Animals (Oral Glucose Tolerance Test $\{$ Ogtt $\}$ )}

The OGTT was performed on overnight fasted animals (18 hours) normal rats. Animals divided into three groups, those are

Group I - $5 \%$ tween 80 treated (Control).

Group II - Catharanthus Pusillus treated (250mg/kg body weight).

Group III - Catharanthus Pusillus treated (500mg/kg body weight).

$0.5 \mathrm{ml}$ of $5 \%$ tween 80 administered to the control group whereas group II treated with $250 \mathrm{mg} / \mathrm{kg}$ body weight of ethanolic extract of Catharanthus Pusillus and group III treated with $500 \mathrm{mg} / \mathrm{kg}$ body weight of ethanolic extract of Catharanthus Pusillus respectively. Glucose ( $1 \mathrm{gm} / \mathrm{kg}$ ) was fed $30 \mathrm{~min}$. after pretreatment with 0.5 $\mathrm{ml}$ of 5\% tween 80 and ethanolic extract of Catharanthus Pusillus Blood glucose levels were measured immediately drawing the blood from tail vein at $0,60,120,180,300$ minutes after glucose load to access the effect of extract on blood glucose levels of glucose loaded animals. Blood glucose levels were determined by the glucose oxidase method using glucometer (Accuchek active) ${ }^{[9]}$. Results were tabulated in table. 1

The percent induced glycemia (\% IG) following oral glucose load at different time intervals was calculated for the control and treated groups as follows:

$$
\% \mathrm{IG}=\frac{G x-G o}{G o} \times 100
$$

Where $G$ o is the initial glycemia $(\mathrm{mg} / \mathrm{dl})$ and $G x$ the glycemia $(\mathrm{mg} / \mathrm{dl})$ at different time intervals after the oral glucose load.

\subsection{Induction of Diabetes}

Initial determination of 12 hours fasting blood glucose levels, blood drawn from tail vein. After determination animals were given single I.P injection of streptozotocin at dose $50 \mathrm{mg} / \mathrm{kg}$ (freshly dissolved in physiological saline) and blood levels of each rat was determined after 72 hours Streptozotocin (STZ) administration for the confirmation of diabetes. Rats with blood glucose level above $250 \mathrm{mg} / \mathrm{dl}$ were considered as diabetics and used subsequently ${ }^{[6]}$.

\subsection{Hypoglycemic Activity}

Hypoglycemic activity performed on overnight fasted (18 hours) 30 rats (24 diabetic rats and 6 normal rats). The animals divided into five groups, those are

Group I - Normal.

Group II - Diabetic control

Group III - Streptozotocin + Glibenclamide ( $5 \mathrm{mg} / \mathrm{kg}$, p.o).

Group IV - Streptozotocin $+250 \mathrm{mg} / \mathrm{kg}$ body weight of ethanolic extract of Catharanthus Pusillus.

Group V - Streptozotocin $+500 \mathrm{mg} / \mathrm{kg}$ body weight of ethanolic extract of Catharanthus Pusillus.

Group I were administered orally with $2 \%$ gum acacia (vehicle) whereas group II received streptozotocin, group III received glibenclamide $(5 \mathrm{mg} / \mathrm{kg}$, p.o) and group III and IV were administered with $250 \mathrm{mg} / \mathrm{kg}$ and $500 \mathrm{mg} / \mathrm{kg}$ body weight of ethanolic extract of Catharanthus Pusillus suspended in $2 \%$ gum acacia for 14 consecutive days. The animal dose has been derived from the human dose by using standard dose ratios. The blood samples collected from the tail vein of rats immediately before and 1, 5, 7 and 14 days after administration of formulation. The blood glucose levels were determined by the glucose oxidase method using glucometer (Accucheck active) ${ }^{[9]}$. Results were tabulated in table 2.

\subsection{Statistical Analysis}

All the values were expressed as mean \pm SEM (standard error mean) $n=6$ rats. The differences were compared using one way analysis of variance (ANOVA) followed by Dunnett's $t$ test. P values $<0.001,0.01$ and 0.05 were considered as significant.

\section{RESULTS}

\subsection{Effect of ethanolic extract of catharanthus pusillus on glucose loaded rats}

The ethanolic extract were subjected to screening for anti hyperglycemic activity by oral glucose tolerance test in albino rats and both $250 \mathrm{mg} / \mathrm{kg}$ and $500 \mathrm{mg} / \mathrm{kg}$ body weight doses possessed significant antihyperglycemic activity the blood glucose levels are showed in table 1 . 
TABLE. 1

\begin{tabular}{|l|l|l|l|l|l|l|l|l|}
\hline S.No & Drug/Control & \multirow{2}{*}{$\begin{array}{l}\text { Body } \\
\text { Weight }\end{array}$} & \multicolumn{3}{l|}{ Blood Glucose Level mg/dl } \\
\cline { 4 - 9 } & & & $0 \mathrm{hr}$ & $1 \mathrm{hr}$ & $2 \mathrm{hr}$ & $3 \mathrm{hr}$ & $5 \mathrm{hr}$ & $24 \mathrm{hr}$ \\
\hline 1 & $\begin{array}{l}5 \% \text { tween } 80 \\
\text { (Control) }\end{array}$ & $142 \pm 2.8$ & $80 \pm 5.6$ & $125 \pm 1.9$ & $126 \pm 3.7$ & $119 \pm 2.6$ & $106 \pm 5.4$ & $98 \pm 1.4$ \\
\hline 2 & $\begin{array}{l}250 \mathrm{mg} / \mathrm{kg} \text { Body } \\
\text { Weight } \\
\text { ethanolic extract } \\
\text { of C.Pusillus }\end{array}$ & $170 \pm 3.9$ & $96 \pm 3.8$ & $169 \pm 4.3^{* * *}$ & $122 \pm 1.7^{* *}$ & $115 \pm 2.4^{* *}$ & $111 \pm 3.2^{*}$ & $100 \pm 5.9^{*}$ \\
\hline 3 & $\begin{array}{l}500 \mathrm{mg} / \mathrm{kg} \text { Body } \\
\text { Weight } \\
\text { ethanolic extract } \\
\text { of C.Pusillus }\end{array}$ & $150 \pm 5.4$ & $98 \pm 2.5$ & $153 \pm 1.2^{* *}$ & $108 \pm 2.9^{* *}$ & $85 \pm 1.8^{* * *}$ & $70 \pm 4.6^{*}$ & $55 \pm 2.4^{*}$ \\
\hline
\end{tabular}

Values are represented as mean \pm SEM ( $\mathrm{n}=6$ rats). Values are statistically significant at $* \mathrm{P}<0.05$. Ethanolic extract of C. Pusillus compared with 5\% tween 80 treated rats. The ethanolic extract of C. Pusillus at $500 \mathrm{mg} / \mathrm{kg}$ body weight dose level exhibited significant hypoglycemic activity shown in Fig.1.

Figure 1

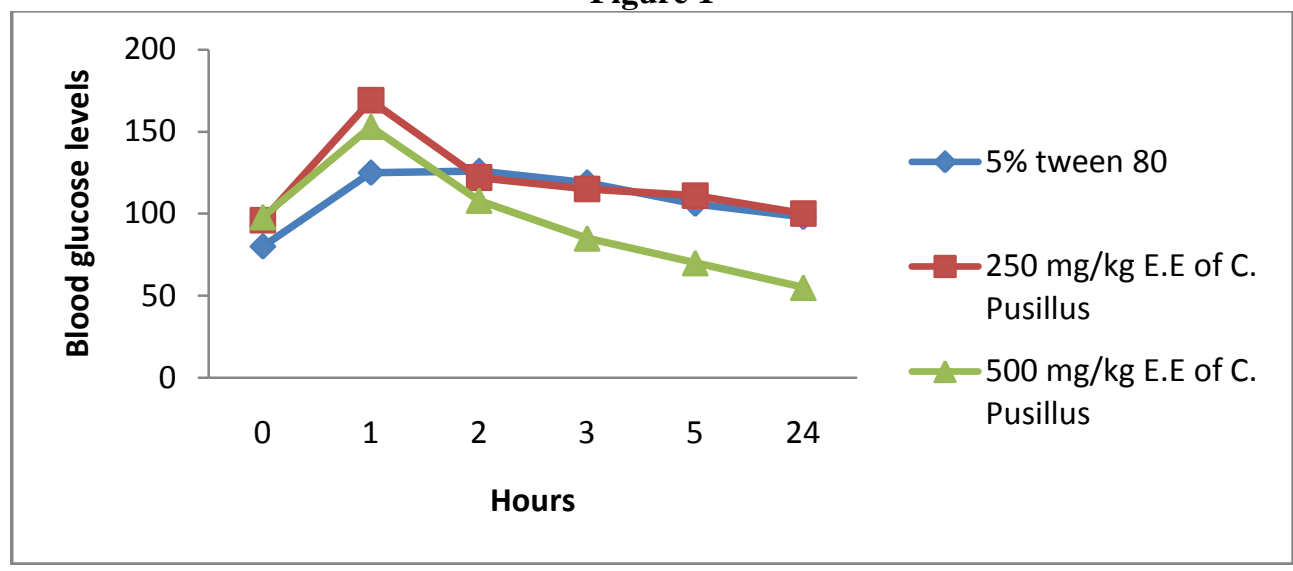

Fig.1. Effect of Catharanthus Pusillus on Glucose loaded Rats OGTTmodel

The percentage reduction of blood glucose levels at $2 \mathrm{hrs}$ is $43.4 \%$ shown by $250 \mathrm{mg} / \mathrm{kg}$ and $78.2 \%$ shown by $500 \mathrm{mg} / \mathrm{kg}$ body weight of ethanolic extract of C.Pusillus. These compared with $5 \%$ tween 80 glucose loaded rats. The reduction of blood glucose levels are shown in Fig.2.

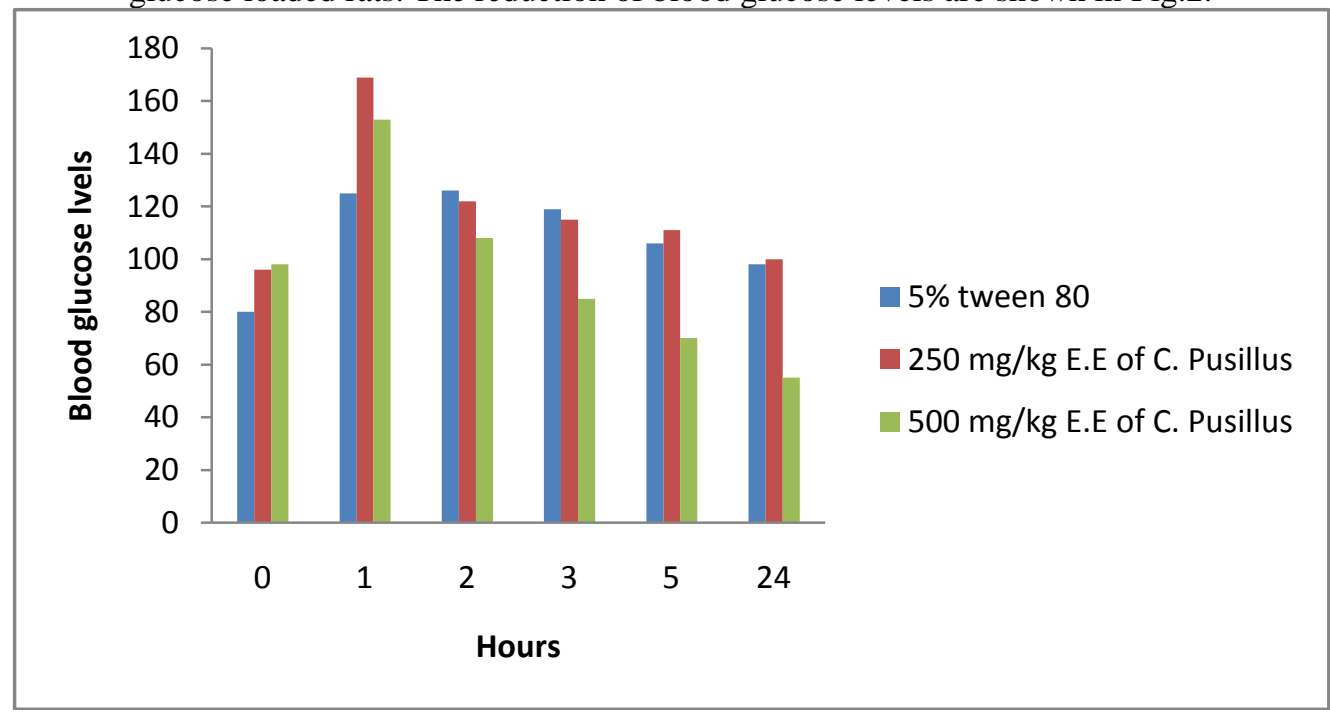

Fig.2. Effect of Catharanthus Pusillus on Blood Glucose levels of albino Rats 


\subsection{Effect of ethanolic extract of catharanthus pusillus on diabetic rats}

The results of the present study demonstrate that the ethanolic extract of Catharanthus puillus had a significant hypoglycemic effect and anti-diabetic activity in streptozotocin induced rat. The blood glucose levels are showed in table. 2.

TABLE. 2

\begin{tabular}{|l|l|l|l|l|l|}
\hline \multicolumn{1}{|c|}{ Groups } & 0 days & \multicolumn{1}{c|}{ 1 days } & 5 days & 7 days & 14 days \\
\hline Normal. & $89.2 \pm 2.5$ & $87 \pm 1.4$ & $88 \pm 2.2$ & $86 \pm 2.4$ & $83.1 \pm 3.6$ \\
\hline Diabetic control & $274 \pm 5.5$ & $270 \pm 3.5$ & $272 \pm 4.2$ & $280 \pm 5.4$ & $283 \pm 2.6$ \\
\hline $\begin{array}{l}\text { Streptozotocin } \\
+ \\
\text { Glibenclamide }\end{array}$ & $280 \pm 4.4$ & $260 \pm 5.6^{*}$ & $245 \pm 3.2^{* *}$ & $205 \pm 2.8^{* * *}$ & $181.2 \pm 1.9^{*}$ \\
\hline $\begin{array}{l}\text { Streptozotocin }+ \\
250 \mathrm{mg} / \mathrm{kg} \text { body } \\
\text { weight of } \\
\text { ethanolic extract } \\
\text { of Catharanthus } \\
\text { Pusillus. }\end{array}$ & $326.3 \pm 6.4$ & $280 \pm 2.6^{*}$ & $261.2 \pm 4.2^{* * *}$ & $246 \pm 2.9^{* * *}$ & $210 \pm 3.8^{* * *}$ \\
\hline $\begin{array}{l}\text { Streptozotocin }+ \\
500 \mathrm{mg} / \mathrm{kg} \text { body } \\
\text { weight } \\
\text { efhanolic extract } \\
\text { of C. Pusillus }\end{array}$ & $394 \pm 4.2$ & $320 \pm 3.6^{* * *}$ & $285 \pm 3.2^{* * *}$ & $254 \pm 1.7^{* *}$ & $205 \pm 4.9^{* *}$ \\
\hline
\end{tabular}

Values are represented as Mean \pm SEM ( $\mathrm{n}=6$ rats). Values are statistically significant at $* * \mathrm{P}<0.01$, *** $\mathrm{P}<0.001$. Diabetic + Catharanthus Pusillus $(250 \mathrm{mg} / \mathrm{kg}, 500 \mathrm{mg} / \mathrm{kg})$ compared with diabetic + glibenclamide and Normal control rats. The ethanolic extract of C. Pusillus showed significant anti-diabetic activity in Fig.3.

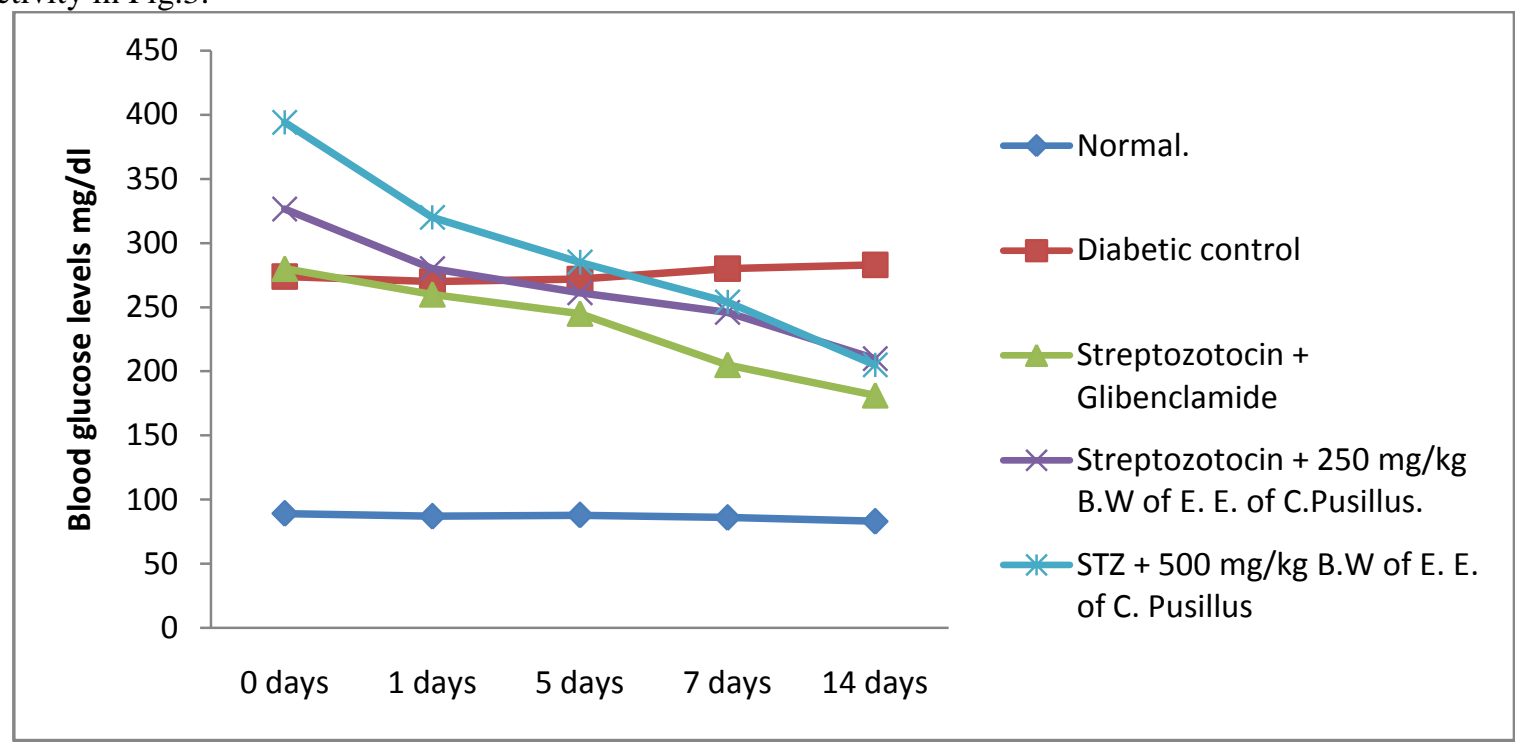

Fig.3. Effect of Catharanthus Pusillus on Fasting blood glucose levels of albino rats

\section{DISCUSSION}

The ethanolic extract of Catharanthus Pusillus at $250 \mathrm{mg} / \mathrm{kg}$ and $500 \mathrm{mg} / \mathrm{kg}$ showed significant antidiabetic activity when compared normal, control and diabetic rats. The anti-diabetic property of ethanolic extract of herb of Catharanthus Pusillus exhibited has dose dependent activity. The anti-diabetic effect of ethanolic extract of herb of Catharanthus Pusillus at the dose of $500 \mathrm{mg} / \mathrm{kg}$ is compared to the standard drug glibenclamide $(5 \mathrm{mg} / \mathrm{kg})$. Our results are supporting it as medicine for the treatment of diabetes.

Streptozotocin is probably the most widely used agents producing insulin dependent diabetes mellitus and non insulin dependent diabetes mellitus in experimental animals. Streptozotocin is a glucosamine nitrosourea compound ${ }^{[15]}$. Streptozotocin enters the B cell via a glucose transporter (GLUT2) and causes 
alkylation of DNA. DNA damage induces activation of poly ADP-ribosylation, a process that is more important for the diabetogenicity of streptozotocin than DNA damage itself. Poly ADP-ribosylation leads to depletion of cellular NAD+ and ATP. Enhanced ATP dephosphorylation after streptozotocin treatment supplies a substrate for xanthine oxidase resulting in the formation of superoxide radicals. Consequently, hydrogen peroxide and hydroxyl radicals are also generated. Furthermore, streptozotocin liberates toxic amounts of nitric oxide that inhibits aconitase activity and participates in DNA damage. As a result of the streptozotocin action, B cells undergo the destruction by necrosis ${ }^{[13]}$.

These also exhibit diabetic complications such as myocardial ${ }^{[8]}$, cardiovascular $^{[5]}$, gastrointestinal ${ }^{[10]}$, tracheal ${ }^{[4]}$, kidney ${ }^{[11]}$, urinary bladder ${ }^{[14]}$ and connective tissue ${ }^{[7]}$ dysfunctions similar to diabetic patients. Streptozotocin induced non insulin dependent diabetes mellitus in rats constitute an invaluable pharmacological tool for screening for anti-diabetic activity because most of the diabetic patients are non insulin dependent in nature.

\section{CONCLUSIONS}

The Catharanthus pusillus possesses both hypoglycaemic and anti-diabetic activities in normoglycaemic and STZ diabetic rats, respectively. The whole plant extracts did not show a consistent effect on normal blood sugar levels but it effectively reversed the Streptozotocin induced changes in the blood sugar level and the beta-cell population in the pancreas. It also showed a protective effect when it was given prior to Streptozotocin administration.

From the above discussion it conclude that ethanolic extract whole plant of Catharanthus puillus at high dose $(500 \mathrm{mg} / \mathrm{kg})$ exhibited significant anti-hyperglycemic activity than whole plant extract at low dose $(300 \mathrm{mg} / \mathrm{kg})$ in Streptozotocin-induced diabetic rats. So it can be used for the treatment of non insulin dependent diabetes mellitus.

\section{REFERENCES}

[1]. Boyle J P, Honeycult A A, Narayan K M, Hoerger T J, Geiss L S, Chen H and Thompson T J, (2001), "Projection of Diabetes Burden Through 2050: Impact of Changing Demography and Disease Prevalence in The US", Diabetes Care, Vol. 24, pp.19361940 .

[2]. Chandra Shekhar Joshi, Ekambaram Sanmnga Priya and Subramanian Venkataraman, (2007), "Hypoglycemic and Antilipid Peroxidative Effects of a Polyherbal Formulation, Diakyur, in Experimental Animal Models", Journal of Health Science, Vol. 53, No.6, pp.734-739.

[3]. Don G (1999), Catharanthus Roseus In: Ross I.A (Ed.), "Medical Plants of The World", Human Press, Totowa, NJ, pp.109-118.

[4]. Fiona R Coulson, David B Jacoby and Allison D Fryer, (2002), "Increased Function of Inhibitory Neuronal $\mathbf{M}_{2} \mathbf{M u s c a r i n i c}^{-}$ Receptors in Trachea and Ileum of Diabetic Rats", British Journal of Pharmacology, Vol.135, No. 6, 1355-1362.

[5]. Jagdish Kakadiya, Haresh Mulani and Nehal Shah, (2010), "Protective Effect of Hesperidin on Cardiovascular Complication in Experimentally Induced Myocardialinfarction in Diabetes in Rats”, Journal of Basic and Clinical Pharmacy, Vol. 1, No. 2, pp. 85-91.

[6]. Karuna Rasineni, Ramesh Bellam Konda, Sreenivasa Reddy Singareddy and Saralakumari Desireddy, (2010), "Antihyperglycemic Activity of Catharanthus Roseus Leaf Powder in Streptozotocin Induced Diabetic Rats" Pharmacognosy Res., Vol.2, No.3, pp.195-201.

[7]. Kerrie J. Way, Keiji Isshiki, Kiyoshi Suzuma, Tamotsu Yokota, Dmitriy Zvagelsky, Frederick J. Schoen, George E. Sandusky, Penelope A. Pechous, Chris J. Vlahos, Hisao Wakasaki and George L. King, (2002), "Expression of Connective Tissue Growth Factor is Increased in Injured Myocardium Associated With Protein Kinase C B2 Activation And Diabetes", Diabetes, Vol.51, No.9, pp.2709-2718.

[8]. Marfella R, Amico M D, Di Filippo C, Piegari E, Nappo F, Esposito K, Berrino L, Rossi F, and Giugliano D, (2002), "Myocardial Infarction In Diabetic Rats: Role of Hyperglycaemia on Infarct Size and Early Expression of Hypoxia-Inducible Factor", Diabetologia, Springer-Verlag, Vol.45, pp. 1172-1181.

[9]. Mohammed Fazil Ahmed, Syedmohammed Kazim, Syed Safiullah Ghori, Syeda Sughramehjabeen, Shaik Rasheed Ahmed, Shaikmehboob Ali, and Mohammed Ibrahim, (2010), "Antidiabetic Activity of Vinca Rosea Extracts in Alloxan-Induced Diabetic Rats", International Journal of Endocrinology, Vol.2010,

[10]. pp. 1-6.

[11]. Nowak T V, Johnson C P, Kalbfleich J H, Roza A M, Wood C M, Weisbruch J P and Soergel K H, (1995), "Highly Variable Gastric Emptying in Patients With Insulin Dependent Diabetes Mellitus”, Vol. 37, No. 1, pp. 23-29.

[12]. Raffel, Pitsakis P, Levison S P And Levion M E, (1981), "Experimental Candida Albicans, Staphylococcus Aureus, and Streptococcus Faecalis Pyelonephritis in Diabetic Rats", American Society For Microbiology, Vol. 34, No.3, pp. 773-779.

[13]. Som Nath Singh, Praveen Vats, Shoba Suri, Radhey Shyam, Kumria M.M.L, Ranganathan S and Sridharan K (2001), "Effect of an Antidiabetic Extract of Catharanthus Roseus on Enzymic Activities In Streptozotocin Induced Diabetic Rats" Journal of Ethnopharmacology, Vol. 76, pp. 269-277.

[14]. Szkudelski T. (2001), "The Mechanism of Alloxan and Streptozotocin Action in B Cells of The Rat Pancreas", Physiological Research, Vol.50, No. 6, pp.537-546.

[15]. Teeraporn Katisart, (2011), "Transient Receptor Potential Function In Bladder From Control and Streptozotocin Treated Rats", $\mathrm{Ph}$. D Thesis, Faculty of Health and Human Sciences, University of Hertfordshire, U K.

[16]. Tom Anderson, Philip S. Schein, Mary G. M. C. Menamin, and David A. Cooney (1974), "Streptozotocin Diabetes, Correlation with Extent of Depression of Pancreatic Islet Nicotinamide Adenine Dinucleotide", The Journal of Clinical Investigation, Vol. 54, pp.672-677.

[17]. Tripati K D, (2006) "Essentials of Medical Pharmacology", Jaypee Brothers Medical Publishers (P) LTD, $6^{\text {th }}$ Edition, pp. 255272. 